Original article

\title{
Babesia bovis and Babesia bigemina infection levels estimated by qPCR in Angus cattle from an endemic area of São Paulo state, Brazil
}

\author{
R. Giglioti ${ }^{\mathrm{a}, *}$, H.N. Oliveira ${ }^{\mathrm{a}}$, C.H. Santana ${ }^{\mathrm{a}}$, A.M.G. Ibelli ${ }^{\mathrm{b}}$, T.A. Néo $^{\mathrm{c}}$, T.B. Bilhassi $^{\mathrm{a}}$, \\ M.D. Rabelo ${ }^{d}$, R.Z. Machado ${ }^{\text {a }}$, L.G. Brito ${ }^{\mathrm{e}}$, M.C.S. Oliveira ${ }^{\mathrm{d}}$ \\ a Universidade Estadual Júlio de Mesquita Filho, Jaboticabal, SP, Brazil \\ b Embrapa Suínos e Aves, Concórdia, SC, Brazil \\ ${ }^{c}$ Universidade Federal de São Carlos, SP, Brazil \\ d Embrapa Pecuária Sudeste, São Carlos, SP, Brazil \\ e Embrapa Rondônia, Porto Velho, RO, Brazil
}

\section{A R T I C L E I N F O}

\section{Article history:}

Received 8 October 2015

Received in revised form

16 December 2015

Accepted 10 February 2016

Available online 11 February 2016

\section{Keywords:}

Babesiosis

R. microplus

qPCR

Resistance

\begin{abstract}
A B S T R A C T
The levels of infection by Babesia bovis and Babesia bigemina were estimated by absolute quantification through the quantitative PCR technique (qPCR). Fifty-one contemporaneous Angus cattle were evaluated on two occasions. The number of standard female Rhipicephalus microplus ticks present on the left side of the body was counted and blood samples were drawn from the tail vein into tubes containing the anticoagulant EDTA. The blood samples were submitted to DNA extraction and used to quantify the number of copies (NC) of DNA from B. bovis and B. bigemina by qPCR. The data on tick count and number of DNA copies were transformed for normalization and analyzed by a mixed model method. A multivariate model with repeated measures of the same animal, including the effects of collection, parasite species and their interaction, was used. The repeatability values were obtained from the matrix of (co)variances and were expressed for each species. The correlations between the counts of different species on the same animal, in the same collection or different collections, were also estimated. The results showed the qPCR could distinguish the two between infection by the two Babesia species. Infection levels by B. bovis and B. bigemina were detected in $100 \%$ and $98 \%$ of the animals, respectively. Significant differences were found $(P<0.05)$ between the NC of the two Babesia species, B. bovis $1.49 \pm 0.07$ vs. B. bigemina $0.82 \pm 0.06$. Low repeatabilities were found for the counts of $R$. microplus and NC of $B$. bovis and B. bigemina: 0.05, 0.10 and 0.02 , respectively. The correlations between $R$. microplus count and $\mathrm{NC}$ of $B$. bovis and B. bigemina were both very near zero. However, an association was observed between the NC of the two species, with a correlation coefficient of 0.30 for measures from the same collection. The absence of associations between the quantity of DNA from $B$. bovis and B. bigemina and the tick counts suggests that the variation of parasitemia by the hemoparasites did not depend on the tick infestation levels at the moment of each collection. The repeatability values estimated indicate that under the study conditions, the variations in the tick infestation levels and of parasitemia by B. bovis and B. bigemina depend more on factors related to each collection than on intrinsic factors of the animal.
\end{abstract}

(c) 2016 Elsevier GmbH. All rights reserved.

\section{Introduction}

Babesiosis causes morbidity and mortality in cattle herds throughout the world (McCosker, 1981), although it occurs with greater frequency in tropical and temperate regions (Figueroa et al., 1998). In Brazil, Babesia bovis and Babesia bigemina

\footnotetext{
* Corresponding author at: Embrapa Pecuária Sudeste, Rodovia Washington Luiz, Km 234, CP 339, 13560-970 São Carlos, São Paulo, Brazil.

E-mail address: gigliotirodrigo@gmail.com (R. Giglioti).
}

are the agents that cause bovine babesiosis, and the cattle tick Rhipicephalus microplus is considered to be the only vector (Guglielmone, 1995). Both young and adult animals are susceptible to the disease when exposed for the first time to ticks. However, young animals have stronger innate resistance. This phenomenon, unusual in the case of infectious diseases, is known as "inverse age resistance". Therefore, the symptoms of the disease can be attenuated if the first infection occurs when the animals are very young. After recovery, low parasitemia levels persist for long periods without causing apparent harm to the animals (Zintl et al., 2005). 
In regions where the vector $R$. microplus is present throughout the year, animals are typically infected while young, after which constant reinfection maintains parasitemia at subclinical levels, guaranteeing lifetime immunity (Mahoney and Ross, 1972). This situation, called endemic stability, occurs virtually throughout Brazil. Nevertheless, clinical cases can appear in calves with ages between 30 and 120 days, a period that coincides with a significant fall in the levels of colostral antibodies (Madruga et al., 1984), although humoral immunity appears to be independent of the resistance level of calves (Guglielmone et al., 1997). Farms located in regions of endemic stability with inadequate tick control are also subject to babesiosis outbreaks (Sserugga et al., 2003).

Several studies have shown that genetic factors are associated with resistance to tick infestations and babesiosis, with Bos taurus indicus animals being more resistant compared to B. t. taurus (Guglielmone, 1995; Bock et al., 1997; Jonsson et al., 2008; Piper et al., 2010; Bilhassi et al., 2014). This finding led Brazilian stockbreeders mainly to use zebu animals, so that at present about $80 \%$ of the nation's herd is composed of this breed and its crosses (Tizioto et al., 2012).

Techniques based on PCR are increasingly used to diagnose diseases, principally because of their high sensitivity and specificity (Figueroa et al., 1992; Smeenk et al., 2000; Oliveira et al., 2005; Oliveira-Sequeira et al., 2005; Guerrero et al., 2007; Buling et al., 2007). However, conventional PCR tests only allow qualitative detection of infection. In contrast, the quantitative real-time PCR technique (qPCR) overcomes these limits, and besides offering a simpler and more efficient diagnostic option, enables quantifying the number of copies of Babesia DNA fragments in samples extracted from cattle blood. Using this technique, Bilhassi et al. (2014) found significant differences in the levels of infection by $B$. bovis in animals of different ages and genetic groups (B. t. taurus and $B$. t. indicus). To our knowledge, no similar studies have been reported in the literature carried out with animals of a specific breed, living under conditions of endemic stability for babesiosis. There also is no information that permits verifying whether the infection level can be attributed to intrinsic animal factors (genetic and non-genetic) and the influence of the level of infestation by $R$. microplus on the levels of infection by Babesia species. Thus, the aims of this experiment were: (i) to find indicators of resistance/susceptibility to babesiosis by applying qPCR to quantify the DNA from B. bovis and B. bigemina in blood samples of Angus cattle; (ii) to estimate the repeatability of these measurements; and (iii) to investigate the occurrence of associations of the levels of infection by the two Babesia species, between each other and with the $R$. microplus counts.

\section{Materials and methods}

\subsection{Animals and sample collection}

We used 51 Angus males, with age about 24 months, from a herd kept in the municipality of José Bonifácio, São Paulo state, Brazil $\left(21^{\circ} 03^{\prime} 10^{\prime \prime} \mathrm{S}\right.$ and $\left.49^{\circ} 41^{\prime} 18^{\prime \prime} \mathrm{W}\right)$, where infestations by the tick $R$. microplus occur throughout the year. The animals were evaluated on two occasions, in May 2012 (autumn) and July 2012 (winter), during which the numbers of $R$. microplus ticks longer than $4.5 \mathrm{~mm}$ were counted on the left side of each animal (Utech et al., 1978; Hermans et al., 1994). At the same time, blood samples for DNA extraction were obtained from the tail vein using Vacuteiners ${ }^{\circledR}$ (Becton Dickinson) containing the anticoagulant EDTA.

The animals of the herd studied were submitted to strategic treatments with a commercial acaricide based on pyrethroids and organophosphates (Colosso ${ }^{\circledR}$, Ourofino Saúde Animal).
The treatments were suspended in the 30 days before the tick counts and blood sample collections.

This experiment is in agreement with ethical principles of animal experimentation of Embrapa Southeast Livestock ethics committee for animal experiments (CEUA-EMBRAPA).

\subsection{DNA extraction}

The genomic DNA for quantification of DNA from B. bovis and $B$. bigemina was extracted from $300 \mu \mathrm{L}$ of each blood sample, using the illustra blood genomicPrep Mini Spin ${ }^{\circledR}$ kit (GE Healthcare), following the vendor's recommendations, according to the protocol for extraction of genomic DNA from between 50 and $300 \mu \mathrm{L}$ of blood.

\section{3. $q P C R$ reactions}

The quantitative polymerase chain reactions were carried out with a CFX ${ }^{\mathrm{TM}}$ Real-Time PCR Detection System from BioRad, with the primers cbosg 1 (forward) 5'-TGTTCCTGGAAGCGTTGATTC$3^{\prime}$ and cbosg 2 (reverse) 5'-AGCGTGAAAATAACGCATTGC-3' and cbisg 1 (forward) 5'-TGTTCCAGGAGATGTTGATTC-3' and cbisg 2 (reverse) 5'-AGCATGGAAATAACGAAGTGC-3' (Buling et al., 2007), which flank the gene fragment of cytochrome $B$ of $B$. bovis and $B$. bigemina, respectively. Each produces amplicons with 88 base pairs (Buling et al., 2007; Salem et al., 1999). Genomic DNA extracted from isolates of $B$. bovis and $B$. bigemina (kindly provided by Professor Rosângela Zacarias Machado of Unesp de Jaboticabal, São Paulo) were used to construct the calibration curve and as positive control.

The qPCR was conducted in a volume of $12 \mu \mathrm{L}$, with $5 \mu \mathrm{L}$ of SsoFast ${ }^{\mathrm{TM}}$ EvaGreen ${ }^{\circledR}$ Supermix (BioRad), $0.22 \mu \mathrm{M}$ of each primer (cbosg 1 and 2; cbisg 1 and 2), $4.4 \mu \mathrm{L}$ of ultrapure water (Invitrogen, USA) and $2.0 \mu \mathrm{L}$ of DNA sample (genomic DNA extracted from $300 \mu \mathrm{L}$ of blood). The thermocycle conditions were one step of $2 \mathrm{~min}$ at $95^{\circ} \mathrm{C}$, followed by 45 cycles at $95^{\circ} \mathrm{C}$ for $5 \mathrm{~s}$ and $57^{\circ} \mathrm{C}$ (annealing/extension) for $30 \mathrm{~s}$. To prevent contamination, pipettes with barrier tips were used. The samples were analyzed in duplicate, as were the positive and negative controls (for the negative control, $2 \mu \mathrm{L}$ of water was added in the reaction instead of the DNA solution).

To assess the specificity of the primers for detection of $B$. bovis and $B$. bigemina in the qPCR, a test with two reactions was used. The first reaction employed the primers cbosg 1 and 2 (B. bovis) in samples from animals and isolates of $B$. bovis and $B$. bigemina. The second reaction contained the same samples and $B$. bovis and $B$. bigemina isolates, but the primers were cbisg 1 and 2 (B. bigemina). The specificity was determined based on the results of the amplification and the melting curve values.

\subsection{Construction of calibration curve and quantification of the number of copies}

To construct the calibration curve, DNA samples from the isolates of the two species were amplified using the specific primers for $B$. bovis and B. bigemina (cbosg and cbisg). The PCR products were purified using the PureLink ${ }^{\mathrm{TM}}$ PCR Purification Kit (Invitrogen ${ }^{\mathrm{TM}}$ ), cloned using the $\mathrm{pGEM}^{\circledR}$-T Easy Vector System (Promega, Madison, USA), and then the recombinant clones were transformed in Escherichia coli $\mathrm{DH} 5 \alpha$ cells. The white colonies were selected, amplified to confirm the vector insert and then grown in SOB medium at $37 \pm 1^{\circ} \mathrm{C}$ overnight under shaking. The DNA was extracted using the PureLink ${ }^{\circledR}$ Quick Plasmid Miniprep Kit (Invitrogen ${ }^{\mathrm{TM}}$ ) and sequenced with an Applied Biosystems ABI Prism 3130 Avant ${ }^{\circledR}$ genetic analyzer and submitted to BLAST analysis to confirm the sequences obtained (Altschul et al., 1990). 
To estimate the number of DNA copies (NC), calibration curves were standardized from the cloned products from the $B$. bovis and $B$. bigemina isolates. The cloned products were quantified in a NanoDrop ND-1000 spectrophotometer. Based on the known value, each product was diluted in series $\left(10^{-10}\right.$ to $\left.10^{-1}\right)$ and the quantification ranges were determined for each species. The dilutions based on the calibration curve of each cloned isolate were submitted to the qPCR tests together with the samples and controls to estimate the NC of DNA from $B$. bovis e and B. bigemina. The reaction efficiency (E) (Pfaffl, 2001; Vandesompele et al., 2002), expressed as a percentage, was determined by the following formula:

$\% E=\left(10^{(-1 / \text { Slope })}-1 \times 100\right)$

where Slope $=$ slope of the derivative (tangent line) of the calibration curve.

The NC of molecules from the target DNA at each dilution was calculated by the formula described by Ke et al. (2006): NC $(\mu \mathrm{L})=\left[\left(6.022 \times 10^{23} \quad(\right.\right.$ copies $/ \mathrm{mol}) \times$ concentration $\left.(\mathrm{g} / \mathrm{mol})\right) /$ molecular mass $(\mathrm{g} / \mu \mathrm{L})]$, where $6.022 \times 10^{23}$ is Avogadro's number and the molecular mass is the average molecular weight of the molecule from the double strand nucleotide $(330 \times 2)$ multiplied by the size of the cloned fragment.

The NC value found in the dilutions from the calibration curves were used to establish a regression equation allowing estimation of the NC values for the DNA from B. bovis and B. bigemina for each sample. These analyses were performed by the software that comes with the BioRad CFX96 system. The samples that presented a deviation greater than 0.5 of the quantitative cycle $\left(C_{\mathrm{q}}\right)$ in relation to the duplicate were analyze again.

\subsection{Statistical analysis}

The data from the $R$. microplus counts and NC were transformed into $\log 10(n+1)$ for the purpose of approximating the normal distribution. After transformation, the data were analyzed using the mixed models method. A multivariate model with repeated measures from the same animal, including the effect of collection, parasite species and their interaction, with fixed effects was used to analyze the $R$. microplus counts and NC values for the two species. The structure of the (co)variance matrix (symmetric) was specified according to the following model:

$\left[\begin{array}{cccccc}\sigma_{I}^{2} & \sigma_{I I_{12}} & \sigma_{I O_{11}} & \sigma_{I O_{12}} & \sigma_{I T_{11}} & \sigma_{I T_{12}} \\ \sigma_{I I_{12}} & \sigma_{I}^{2} & \sigma_{I O_{12}} & \sigma_{I O_{11}} & \sigma_{I T_{12}} & \sigma_{I T_{11}} \\ \sigma_{I O_{11}} & \sigma_{I O_{12}} & \sigma_{O}^{2} & \sigma_{O O_{12}} & \sigma_{O T_{11}} & \sigma_{O T_{12}} \\ \sigma_{I O_{12}} & \sigma_{I O_{11}} & \sigma_{O O_{12}} & \sigma_{O}^{2} & \sigma_{O T_{12}} & \sigma_{O T_{11}} \\ \sigma_{I T_{11}} & \sigma_{I T_{12}} & \sigma_{O T_{11}} & \sigma_{O T_{12}} & \sigma_{T}^{2} & \sigma_{T T_{12}} \\ \sigma_{I T_{12}} & \sigma_{I T_{11}} & \sigma_{O T_{12}} & \sigma_{O T_{11}} & \sigma_{T T_{12}} & \sigma_{T}^{2}\end{array}\right]$

where $\sigma_{K}^{2}$, variance component of the counts in each collection of species $K(K=I, O, T$; with species $I=B$. bigemina, $O=B$. bovis and $T=R$. microplus); and $\sigma_{K L_{i j}}$, covariance component between the count from species $K$ in collection $i(i=1,2)$ and the count from species $L(L=I, O, T)$ in collection $j(j=1,2)$.

The repeatability levels were obtained from the (co)variance matrix, expressed for each species as the correlation between the measures taken from the same individual in the two collections. Likewise, correlations were estimated between the counts from different species taken from the same animal, in the same or different collections. The MIXED routine from the SAS statistical package was employed for the analyses, and the option $\operatorname{LIN}(q)$ from the command line REPEATED was used to specify the (co)variance matrix.

\section{Results}

\subsection{Specificity and sensitivity of the qPCR assays}

The results of specificity assay indicated that the primers were specific each to $B$. bovis and $B$. bigemina. It can be seen in Fig. 1a that when the primers cbosg 1 and 2 were used in the reaction, they only amplified reaction products that contained isolates of $B$. bovis, not those containing isolates of $B$. bigemina. The inverse was found when using primers cbisg 1 and 2 . The tests on the samples (Fig. 1b) enabled distinguishing the two Babesia species. The melting curve determined for $B$. bovis showed a temperature of $77.5^{\circ} \mathrm{C}$ while for $B$. bigemina it was $76.0^{\circ} \mathrm{C}$. The DNA sequences obtained for each of the species were identical to each other and the same as the following cytochrome b sequences deposited in the GenBank: AB499088.1, GQ214235.1, FJ426365.1, FJ426366.1 and FJ426367.1 for B. bovis and LK054939.1, AB499085.1, GQ214234.1, FJ426362.1 and FJ426363.1 for B. bigemina.

The quantification of the NC of the DNA from $B$. bovis and $B$. bigemina, for both species, was possible in a dilution range from $10^{-10}$ to $10^{-3}$, with the highest dilution of each calibration curve presenting a quantification sensitivity limit (last point on the curve) of approximately 12 copies of the target DNA (average of the quantitative cycle of 38). We conducted a total of eight qPCR runs, four for quantification of the NC of each hemoparasite species. The reaction efficiency $(E)$ measures, coefficient of determination $\left(r^{2}\right)$ and slope found in the tests were near those considered ideal (Table 1 ), showing that the tests precisely quantified the DNA from these parasites, within the limits considered. There was little variation of $\mathrm{E}$ between the tests, as shown by the low average standard deviations in the quantification of the DNA from B. bovis and B. bigemina (Table 1).

\subsection{Detection of B. bovis and B. bigemina by $q P C R$}

The qPCR assays allowed detecting $B$. bovis and $B$. bigemina present in the genomic DNA obtained from the Angus cattle blood samples. According to the tests, 100 and $98 \%$ of the animals were infected by B. bovis and B. bigemina, respectively. Only two samples gave negative results, i.e., no amplification of the target DNA in the samples, in both cases for B. bigemina and both obtained in the second collection. These two samples were submitted to a new test, with negative results again. Contamination of the negative controls did not occur in any test. According to Bustin et al. (2009), the minimum number of copies it would be possible to detect, considering a Poisson distribution and 95\% probability of including at least one copy in the PCR, would be three.

\subsection{Counting of R. microplus and qPCR for B. bovis and B. bigemina}

The statistical analyses showed a significant effect of species $(p<0.05)$, which was expected since the measure for each parasite can be considered a different trait. There was also a significant effect for collection $(p<0.05)$, but not for the interaction between species and collection, showing the behavior was similar for the three species in the two collections. The averages, presented in Table 2, show higher values in the first collection than in the second for all the species.

As was the case of the higher percentage of animals quantified for $B$. bovis, the average NC value for this parasite is also higher 


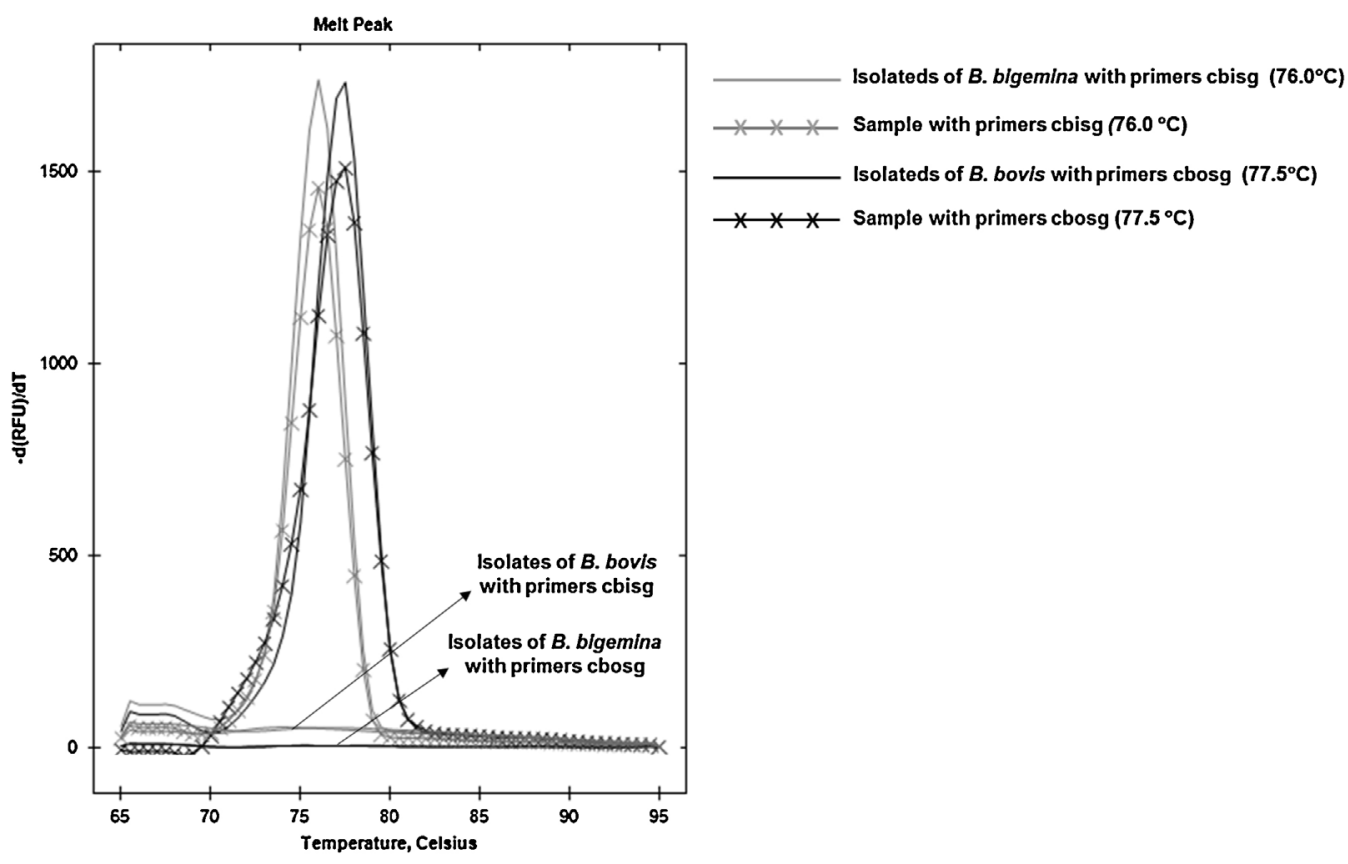

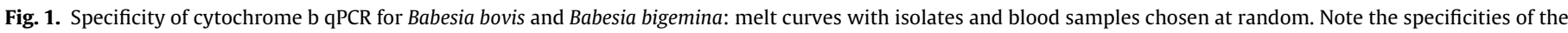
primers for the amplifications of $B$. bovis $\left(77.5^{\circ} \mathrm{C}\right)$ and $B$. bigemina $\left(76.0^{\circ} \mathrm{C}\right)$. Smooth lines = blood samples; cross lines $=$ isolates

Table 1

Reaction efficiency $(E)$, coefficient of determination $\left(r^{2}\right)$ and slope from the tests conducted to quantify the DNA of $B$. bovis and B. bigemina by the qPCR technique.

\begin{tabular}{|c|c|c|c|c|c|c|}
\hline \multirow[t]{2}{*}{ Test } & \multicolumn{3}{|l|}{ B. bovis } & \multicolumn{3}{|l|}{ B. bigemina } \\
\hline & $E$ & $r^{2}$ & Slope & $E$ & $r^{2}$ & Slope \\
\hline 1 & 99.60 & 0.994 & 3.332 & 100.00 & 0.998 & 3.322 \\
\hline 2 & 99.90 & 0.999 & 3.324 & 101.30 & 0.998 & 3.292 \\
\hline 3 & 98.50 & 0.999 & 3.259 & 100.40 & 0.995 & 3.311 \\
\hline 4 & 99.50 & 0.999 & 3.334 & 100.80 & 0.997 & 3.303 \\
\hline Mean \pm SD & $99.38 \pm 0.61$ & $0.997 \pm 0.002$ & $3.312 \pm 0.03$ & $100.62 \pm 0.56$ & $0.997 \pm 0.001$ & $3.307 \pm 0.012$ \\
\hline
\end{tabular}

Table 2

Means and standard deviations of the number of copies (NC) of DNA from B. bovis and $B$. bigemina $(\log 10+1$ transformed), analyzed by the qPCR technique.

\begin{tabular}{llll}
\hline Collection & 1 & 2 & Mean \\
\hline B. bovis & $1.68 \pm 0.09$ & $1.30 \pm 0.09$ & $1.49 \pm 0.07$ \\
B. bigemina & $0.95 \pm 0.09$ & $0.68 \pm 0.09$ & $0.82 \pm 0.06$ \\
R. microplus & $1.18 \pm 0.05$ & $0.95 \pm 0.05$ & $1.07 \pm 0.03$ \\
\hline
\end{tabular}

than that for B. bigemina in the two collections $(P<0.05)$. The transformed means of the number of DNA copies from $B$. bovis and $B$. bigemina are presented in Table 2.

\subsection{Repeatability and associations of R. microplus, B. bovis and B. bigemina}

The joint analyses of the three parasites permitted estimating the repeatability levels for the covariances between the two measures for each species and the variance common to the two measures for each species. The repeatability estimates found for the R. microplus count and NC of B. bovis and B. bigemina DNA were $0.05,0.10$ and 0.02 , respectively. The correlations between the $R$. micropluse count on the one hand and the NC of B. bovis or B. bigemina DNA on the other were very near zero, both when considering the measures obtained in the same collection and between different collections. However, there was an association between the NC values for the two Babesia species, with a correlation coefficient value of 0.30 for measures from the same collection and 0.07 for measures obtained from different collections.

\section{Discussion}

The number of purebred Angus cattle in Brazil is much smaller than the number zebu breeds, but the former is widely used in crosses to improve growth, fat thickness and meat quality traits, especially by breeders using more advanced technology (Lobato et al., 2014). These taurine cattle are considered highly susceptible to ticks (Lemos et al., 1985; Oliveira and Alencar, 1990; Wambura et al., 1998; Bianchin et al., 2007; Da Silva et al., 2007, 2010) and to babesiosis (Bock et al., 1997; Jonsson et al., 2008; Piper et al., 2010), the reason we chose this breed for the experiment. Ticks are common in the region studied and the animals in the herd were monitored for the presence of these parasites and submitted to regular treatments with acaricides. Bilhassi et al. (2014) studied the same herd and their data showed this region can be classified as endemically stable for babesiosis. We used young animals, but ones that had already suffered successive babesiosis episodes, so they did not present clinical signs of infection at the collection times.

There were differences between the two $R$. microplus counts. The numbers were higher in the first count (autumn) than the second one (winter). Some authors have argued that higher tick infections in Brazil can occur in the autumn months (Brum et al., 1987; Veríssimo et al., 1997; Andrade et al., 1998; Kasai et al., 2000), or autumn and winter (Guaragna et al., 1988; Oliveira et al., 1989) or winter (Utech et al., 1978). Da Silva et al. (2010) found that 
the highest cattle tick infestations occurred in winter and autumn, while the lowest were in spring and summer.

The repeatability of the tick counts was very low. This finding contrasts with that of Mackinnon et al. (1991), who calculated repeatability of 0.45 when studying natural infestation by this tick on cattle of different genetic groups. They worked with tick count data recorded during five years. In Brazil, Fraga et al. (2003) studied the tick resistance of Caracu animals by counting standard females and found repeatability of 0.21 . Those authors also observed that the number of counts conducted had a significant influence on the estimate of repeatability. Da Silva et al. (2007) investigated artificial infestation by R.(B.) microplus on cattle of different genetic groups and found repeatability of 0.65 . This value was estimated from four tick counts carried out after artificial infestation, at 14day intervals. According to the authors, a high repeatability value was expected, since the environmental conditions during the study were controlled, in contrast to natural infestations, and the period between counts was brief. It is possible that the low repeatability estimate for the tick counts found by us occurred because we only conducted two counts, as well as the relatively long interval between them. In any event, the value indicates that under the conditions of this experiment, the variation in the environment in which each count was conducted was much more important than the capacity of the animal to maintain levels of infestation. Therefore, it can be concluded that when evaluating animals for tick resistance, a larger number of counts, under more controlled conditions and shorter intervals between counts is desirable.

The qPCR tests employed in this study showed high specificity in quantifying the DNA fragments from B. bovis and B. bigemina, as also described by Buling et al. (2007). The melting curve enabled differentiating the two sequences, and when the specific cloned isolates of each species were used, the primer cbosg only amplified $B$. bovis fragments while cbisg only did so for B. bigemina.

The results of the qPCR tests showed that all the blood samples used in the experiment contained DNA from B. bovis, and $98 \%$ of the same samples contained DNA from $B$. bigemina. These results can be considered reliable, since for each reaction plate we included negative controls where no amplification occurred. This finding corroborates that of Bilhassi et al. (2014), who quantified B. bovis DNA by $\mathrm{qPCR}$ in B. t. indicus, B. t. indicus $\times$ B. t. taurus and B. t. taurus animals and found B. bovis infection prevalences of $96 \%, 98 \%$ and $100 \%$, respectively. To quantify the DNA from $B$. bovis by the qPCR technique in our study, the primers used were sequences of mitochondrial DNA from Babesia species, which flank genes that codify cytochrome b (Buling et al., 2007), thus being multiple-copy genes (Salem et al., 1999; Ríos and Ríos, 2011). The use of these genes might have been responsible for the high sensitivity of the technique used, although similar results were found by Ramos et al. (2011), who used single-copy genes to detect $B$. bovis by qPCR in animals bred in an endemic area.

The repeatability values found for the two collections regarding the number copies of $B$. bovis and B. bigemina DNA for the herd studied were low (respectively 0.02 and 0.10 ). These results demonstrate that the parasitemia of these two species varies greatly between collections from the same individual, i.e., the observation of infection from one observation is not a good indicator of the subsequent observation of the same animal. The estimated correlation of the tick counts and the NC values of $B$. bovis and $B$. bigemina were very near zero, both between the measures from the same collection and between measures from different collections. Although the presence of these ticks is linked to potential infection by pathogens transmitted by them (Lorusso et al., 2013), these results indicate that the tick burden is not the preponderant factor in determining the parasitemia level for $B$. bovis or $B$. bigemina. No studies have been published reporting the correlation between the number of ticks and the number of DNA copies of these two protozoa in cattle blood. The moderate correlation found between the NC for B. bovis and B. bigemina in the same collection indicates that the factors that determine an increase or decrease in parasitemia for one species cause the same variation in the other species. Since the repeatability of the NC was low both for $B$. bovis and B. bigemina, it was natural for the correlations between the measures of the two parasites taken from the same animal in different collections also to be low.

\section{Conclusions}

The qPCR applied in this study enabled estimating the parasitemia by $B$. bovis and $B$. bigemina with good precision and also allowed observing the occurrence of a fluctuation in the levels of these parasites in the animals' blood over time. The absence of associations between the quantity of DNA from $B$. bovis and B. bigemina and the tick counts suggests that the variation of parasitemia by the hemoparasites did not depend on the tick infestation levels. The repeatability values estimated indicate that under the study conditions, the variations in the tick infestation levels and of parasitemia by $B$. bovis and B. bigemina depend more on factors related to each collection than on intrinsic factors of the animal.

\section{Acknowledgments}

Grants for this project was supported by Fundação de Amparo à Pesquisa do Estado de São Paulo (FAPESP) (grants \#2012/00067-5 and \#2011/23833-2) and Brazilian Agricultural Research Corporation (Embrapa).

\section{References}

Altschul, S.F., Gish, W., Miller, W., Myers, E.W., Lipman, D.J., 1990. Basic local alignment search tool. J. Mol. Biol. 215, 403-410.

Andrade, A.B.F., Silva, R.G., Costa, A.J., Rocha, U.F., Landim, V.J.C., 1998. Genetic and environmental aspects of the resistance of zebu cattle to the tick Boophilus microplus. In: Proceedings of the Armidale 6th World Congress on Genetics Applied to Livestock Production, vol. 27, Armidale, NSW, Australia, pp. 339-342.

Bianchin, I., Catto, J.B., Kichel, A.N., Torres, R.A.A., Honer, M.R., 2007. The effect of the control of endo- and ectoparasites on weight gains in crossbred cattle (Bos taurus taurus $\times$ Bos taurus indicus) in the central region of Brazil. Trop. Anim. Health Prod. 39, 287-296.

Bilhassi, T.B., Oliveira, H.N., Ibelli, A.M.G., Giglioti, R., Regitano, L.C.A., Oliveira-Sequeira, T.C.G., Bressani, F.A., Malagó, W., Resende, F.D., Oliveira, M.C.S., 2014. Quantitative study of Babesia bovis infection in beef cattle from São Paulo state, Brazil. Ticks Tick Borne Dis. 5, 234-238.

Bock, R.E., de Vos, A.J., Kingston, T.G., McLellan, D.J., 1997. Effect of breed of cattle on innate resistance to infection with Babesia bovis, B. bigemina and Anaplasma marginale. Aust. Vet. J. 75, 337-340.

Brum, J.G., Ribeiro, P.B., Costa, P.R.P., 1987. Flutuação sazonal de Boophilus microplus (Canestrini, 1987) no município de Pelotas. Arq. Bras. Med. Vet. Zooctec. 39 (6), 891-896.

Buling, A., Criado-Fornelio, A., Asenzo, G., Benitez, D., Barba-Carretero, J.C., Florin-Christensen, M., 2007. A quantitative PCR assay for the detection and quantification of Babesia bovis and B. bigemina. Vet. Parasitol. 147, 16-25.

Bustin, S., Benes, V., Garson, J., 2009. The MIQE guidelines: minimum information for publication of quantitative real-time PCR experiments. Clin. Chem. 55, 611-622.

Da Silva, A.M., de Alencar, M.M., de Almeida Regitano, L.C., de Sena Oliveira, M.C., Barioni, W., 2007. Artificial infestation of Boophilus microplus in beef cattle heifers of four genetic groups. Genet. Mol. Biol. 30, 1150-1155.

Da Silva, A.M., Alencar, M.M., Regitano, L.C.A., Oliveira, M.C.S., 2010. Infestação natural de fêmeas bovinas de corte por ectoparasitas na Região Sudeste do Brasil. Rev. Soc. Bras. Zootec. 39 (7), 1477-1482.

Figueroa, J.V., Alvarez, J.A., Ramos, J.A., Rojas, E.E., Santiago, C., Mosqueda, J.J., Vega, C.A., Buening, G.M., 1998. Bovine babesiosis and anaplasmosis follow-up on cattle relocated in an endemic area for hemoparasitic diseases. Ann. N. Y. Acad. Sci. 849, 1-10.

Figueroa, J.V., Chieves, L.P., Johnson, G.S., Buening, G.M., 1992. Detection of Babesia bigemina-infected carriers by polymerase chain reaction amplification. J. Clin. Microbiol. 30, 2576-2582.

Fraga, A.B., De Alencar, M.M., De Figueiredo, L.A., Razook, A.G., Dos Santos Conçalves Cyrillo, J.N., 2003. Análise de fatores genéticos e ambientais que afetam a infestação de fêmeas bovinas da raça caracu por carrapatos (Boophilus microplus). Rev. Bras. Zootec. 32 (6), 1578-1586. 
Guaragna, G.P., Carvalho, J.B.P., Figueiredo, A.L., Gambini, L.B., Barbosa, M.I.A., 1988 Efeito de fatores genéticos e ambientais na infestação natural de carrapatos (Boophilus microplus, Canestrini) em bovinos leiteiros, vol. 45. Boletim de Industria Animal, Nova Odessa, pp. 19-32.

Guerrero, F.D., Bendele, K.G., Davey, R.B., George, J.E., 2007. Detection of Babesia bigemina infection in strains of Rhipicephalus (Boophilus) microplus collected from outbreaks in South Texas. Vet. Parasitol. 145, 156-163.

Guglielmone, A.A., 1995. Epidemiology of babesiosis and anaplasmosis in South and Central America. Vet. Parasitol. 57, 109-119.

Guglielmone, A.A., Lugaresi, C.I., Volpogni, M.M., Anziani, O.S., Vanzini, V.R., 1997. Babesial antibody dynamics after cattle immunisation with live vaccines, measured with an indirect immunofluorescence test. Vet. Parasitol. 70, 33-39.

Hermans, P., Dwinger, R.H., Buening, G.M., Herrero, M.V., 1994. Seasonal incidence and hemoparasite infection rates of Ixodid ticks (Acari: Ixodidae) detached from cattle in Costa Rica. Rev. Biol. Trop. 42, 623-632.

Jonsson, N.N., Bock, R.E., Jorgensen, W.K., 2008. Productivity and health effects of anaplasmosis and babesiosis on Bos indicus cattle and their crosses, and the effects of differing intensity of tick control in Australia. Vet. Parasitol. 155 (1-2), 1-9.

Kasai, N., Labruna, M.B., Pires, A.V., Louvandini, H., Abdalla, A.L., Gennari, S.G., 2000. Dinâmica populacional de Boophilus microplus (Canestrini, 1887) em bovinos leiteiros mantidos em manejo de pastejo rotativo de capim-elefante. Arq. Bras. Med. Vet. Zootec. 52 (5), 453-458.

Ke, G.M., Cheng, H.L., Ke, L.Y., Ji, W.T., Chulu, J.L., Liao, M.H., Chang, T.J., Liu, H.J., 2006. Development of a quantitative Light cycler real-time RT-PCR for detection ofavian reovirus. J. Virol. Methods 133, 6-13.

Lemos, A.M., Teodoro, R.L., Oliveira, G.P., Madalena, F.E., 1985. Comparative performance of six Holstein-Friesian $\times$ Guzera grades in Brazil. Burdens of Boophilus microplus under field conditions. Anim. Prod. 41, 187-191.

Lobato, J.F.P., Freitas, A.K., Devincenzi, T., Cardoso, L.L., Tarouco, J.U., Vieira, R.M., Dillenburg, D.R., Castro, I., 2014. Brazilian beef produced on pastures: sustainable and healthy. Meat Sci. 98, 336-345.

Lorusso, V., Picozzi, K., de Bronsvoort, B.M.C., Majekodunmi, A., Dongkum, C., Balak, G., Igweh, A., Welburn, S.C., 2013. Ixodid ticks of traditionally managed cattle in central Nigeria: where Rhipicephalus (Boophilus) microplus does not dare (yet?). Parasit. Vectors 6, 171.

Mackinnon, M., Meyer, K., Hetzel, D.J., 1991. Genetic variation and covariation for growth, parasite resistance and heat tolerance in tropical cattle. Livest. Prod. Sci. 27 (2-3), 105-122.

Madruga, C.R., Aycardi, E., Kesller, R.M., Schenk, M.A.M., Figueredo, G.R., Curvo, J.B.E., 1984. Níveis de anticorpos anti-Babesia bigemina e Babesia bovis, em bezerros da raça Nelore, Ibagé e cruzamentos de Nelore. Pesq. Agropec. Bras. 19, 1163-1168.

Mahoney, D.F., Ross, D.R., 1972. Epizootiological factors in the control of bovine babesiosis. Aust. Vet. J. 48, 292-298.

McCosker, P.J., 1981. The global importance of babesiosis. In: Ristic, M., Kreier, J.P. (Eds.), Babesiosis. Academic Press, New York, NY, pp. 1-24.

Oliveira, G.P., Alencar, M.M., Freitas, A.R., 1989. Resistance of cattle to the tick Boophilus microplus. II Natural infestation. Pesq. Agropec. Bras. 24, 1267-1271.
Oliveira, M.C.S., Oliveira-Sequeira, T.C.G., Araujo, J.P., Amarante, A.F.T., Oliveira H.N., 2005. Babesia spp. infection in Boophilus microplus engorged females and eggs in São Paulo State, Brazil. Vet. Parasitol. 130, 61-67.

Oliveira, G.P., Alencar, M.M., 1990. Resistência de bovinos de seis graus de sangue Holandês-Guzerá ao carrapato (Boophilus microplus) e ao berne (Dermatobia hominis). Arq. Bras. Med. Vet. Zootec. 42, 127-135.

Oliveira-Sequeira, T.C.G., Oliveira, M.C.S., Araujo, J.P., Amarante, A.F.T., 2005. PCR-based detection of Babesia bovis and Babesia bigemina in their natural host Boophilus microplus and cattle. Int. J. Parasitol. 35, 105-111.

Pfaffl, M.W., 2001. A new mathematical model for relative quantification in real-time RT-PCR. Nucl. Acids Res. 29, e45.

Piper, E.K., Jackson, L.A., Bielefeldt-Ohmann, H., Gondro, C., Lew-Tabor, A.E., Jonsson, N.N., 2010. Tick-susceptible Bos taurus cattle display an increased cellular response at the site of larval Rhipicephalus (Boophilus) microplus attachment, compared with tick-resistant Bos indicus cattle. Int. J. Parasitol. 40, 431-441.

Ramos, C.A.N., Araújo, F.R., Souza, I.I.F., Bacanelli, G., Luiz, H.L., Russi, L.S., Oliveira, R.H.M., Soares, C.O., Rosinha, G.M.S., Alves, L.C., 2011. Real-time polymerase chain reaction based on msa2c gene for detection of Babesia bovis. Vet. Parasitol. 176, 79-83.

Ríos, S.T., Ríos, L.O., 2011. Principales marcadores moleculares utilizados para la identificación de Babesia bovis y Babesia bigemina. Rev. MVZ Cordoba 16 (2), 2470-2483.

Salem, G.H., Liu, X., Johnsrude, J.D., Dame, J.B., Roman Reddy, G., 1999. Development and evaluation of an extra chromosomal DNA-based PCR test for diagnosing bovine babesiosis. Mol. Cell. Probes 13, 107-113.

Smeenk, I., Kelly, P.J., Wray, K., Musuka, G., Trees, A.J., Jongejan, F., 2000. Babesia bovis and B. bigemina DNA detected in cattle and ticks from Zimbabwe by polymerase chain reaction. J. S. Afr. Vet. Assoc. 71, 21-24.

Sserugga, J.N., Jonsson, N.N., Bock, R.E., More, S.J., 2003. Serological evidence of exposure to tick fever organisms in young cattle on Queensland dairy farms. Aust. Vet. J. 81, 147-152.

Tizioto, P.C., Meirelles, S.L., Veneroni, G.B., Tullio, R.R., Rosa, A.N., Alencar, M.M., Medeiros, S.R., Siqueira, F., Feijó, G.L.D., Silva, L.O.C., Torres, R.A.A., Regitano, L.C.A., 2012. A SNP in ASAP1 gene is associated with meat quality and production traits in Nelore breed. Meat Sci. 92, 855-857.

Utech, K.B.W., Wharton, R.H., Kerr, J.D., 1978. Resistance to Boophilus microplus (Canestrini) in different breeds of cattle. Aust. J. Agric. Res. 29, 885-895.

Vandesompele, J., De Preter, K., Pattyn, F., Poppe, B., Van Roy, N., De Paepe, A., Speleman, F., 2002. Accurate normalization of real-time quantitative RT-PCR data by geometric averaging of multiple internal control genes. Genome Biol. 3 (7), RESEARCH0034.

Veríssimo, C.J., Silva, R.G., Oliveira, A.A.D., Ribeiro, W.R., Rocha, U.F., 1997. Resistência e susceptibilidade de bovinos leiteiros mestiços ao carrapato Boophilus microplus. Bol. Ind. Anim. 54, 1-10.

Wambura, P.N., Gwakisa, P.S., Silayo, R.S., Rugaimukamu, E.A., 1998 Breed-associated resistance to tick infestation in Bos indicus and their crosses with Bos taurus. Vet. Parasitol. 77, 63-70.

Zintl, A., Gray, J.S., Skerrett, H.E., Mulcahy, G., 2005. Possible mechanisms underlying age-related resistance to bovine babesiosis. Parasite Immunol. 27 (4), 115-120. 